\title{
The Extended School Day and Artistic Activities: Analysis of Scientific Production Between 2000 and 2012 in Brazil ${ }^{1}$
}

\author{
Neiva de Assis $^{2}$ \\ Instituto Federal Catarinense, \\ São Francisco do Sul-SC, Brazil
}

\author{
Andrea Vieira Zanella \\ Universidade Federal de Santa \\ Catarina, Florianópolis-SC, Brazil
}

\author{
Luciano Rosa \\ Instituto Federal Catarinense, \\ São Francisco do Sul-SC, Brazil
}

\begin{abstract}
This study addresses the inclusion of artistic activities in the context of after-school programs. We consider it important to map and investigate how the inclusion of these activities, as well as relationships between young individuals and education institutions, have been discussed. Theses and dissertations, available on the CAPES platform between 2000 and 2012, the themes of which were artistic activities included in after-school programs, were analyzed. The method used is defined as "State of the Art". A total of 49 theses and dissertations were found and categories such as main topic and results were analyzed. This analysis highlights new ways of doing research and current opportunities of aesthetic education directed to young individuals. The results show changes in the lives of young individuals participating in educational projects that include Art. Enabling access to aesthetic knowledge within formal educational institutions is essential.
\end{abstract}

Keywords: education, arts, subjectivity, adolescents

\section{Ampliação da Jornada Escolar e Atividades Artísticas: Análise da Produção Científica Entre 2000 e 2012 no Brasil}

\begin{abstract}
Resumo: Este estudo tem como temática as atividades artísticas em contextos de ampliação da Jornada Escolar. Consideramos relevante mapear e investigar o modo como discutem tanto a presença dessas atividades artísticas nesses espaços como também, as relações entre jovens e instituições formadoras. Analisa pesquisas disponíveis no banco de teses e dissertações da CAPES entre 2000 e 2012 que apresentam como temática as atividades artísticas em programas de ampliação do tempo educativo. A metodologia caracteriza-se como "estado da arte". Por isso, realizou-se levantamento e análise de 49 teses e dissertações a partir de categorias, tais como: temática principal de pesquisa e resultados obtidos. Na análise, destacam-se novos modos de fazer pesquisa e às oportunidades de educação estética aos jovens na atualidade. As investigações indicaram, em seus resultados, mudanças ocorridas na vida dos jovens ao participarem de projetos educativos com Arte. Considera-se fundamental oportunizar o acesso aos conhecimentos estéticos por meio dos espaços educativos formais.
\end{abstract}

Palavras-chave: educação, artes, subjetividade, adolescentes

\section{Ampliación de la Jornada Escolar y Actividades Artísticas: Análisis de la Producción Científica Desde 2000 Hasta 2012 en Brasil}

\begin{abstract}
Resumen: Este estudio trata de la inclusión de actividades artísticas en contextos de ampliación del tiempo educativo. Consideramos relevante mapear e investigar el modo como se discuten tanto la presencia de esas actividades artísticas en eses espacios como las relaciones entre jóvenes e instituciones formadoras. Analiza investigaciones disponibles en el banco de tesis y disertaciones de la CAPES entre los años de 2000 y 2012 que presentan como temática las actividades artísticas en programas de ampliación del tiempo educativo. La metodología se caracteriza como "estado del arte". Por eso, fueron identificados y analizados 49 tesis y disertaciones a partir de categorías, tales como: temática principal de investigación y resultados alcanzados. En el análisis, se destacan nuevas formas de hacer investigaciones en el contexto de la educación y las oportunidades de educación estética a los jóvenes actualmente. Las investigaciones indicaron en sus resultados cambios ocurridos en la vida de los jóvenes al participar en proyectos educativos. Se considera fundamental dar la oportunidad de acceder a los conocimientos estéticos por medio de los espacios educativos formales.
\end{abstract}

Palabras clave: educación, artes, subjetividad, adolescentes

The extension of the school day is provided by Law 9394 Art. 34, 2nd paragraph, which establishes the guidelines and bases for Brazilian education, defining the school day

\footnotetext{
1 This manuscript derives from the master's thesis of the first author under the advisory of the second author, defended in the Graduate Psychology Program at the Universidade Federal de Santa Catarina, in 2011.

2 Correspondence address:

Neiva de Assis. Rua Barão do Rio Branco, 377, Sala 202, Centro. CEP 89240-000. São Francisco do Sul-SC, Brazil. E-mail: neiva.assis@ safrancisco.ifc.edu.br
}

to consist of at least four hours of effective work inside the classroom, while the period children remain in school is to be progressively extended (Law No. 9.394, 1996). In 2007, the Ministry of Education formalized the legislation through the program "Mais Educação" (More Education) which, according to Inter-Ministerial Decree No. 17/2007, is characterized by a national policy of education defined as "the Government's strategy to induce extension of the school day" and put into practice what was provided in the law (Ministry of Education, 2009a, p. 5). 
Various educational experiences are intended to contribute to the construction of collective spaces in which young people are the focus of full-time education, such as discussions promoted by the Center for Study and Research in Education, Culture and Communitarian Action (Cenpec, 2013). This organization works within the context of public policy demands for education in Brazil, based on the understanding that the social quality of education depends on grounding socio-educational actions in the territory and on greater inter-sector social policies. Cenpec brings the idea of after-school programs as social protection, as a socioeducational complement to the activities provided at school.

The conception of full-time education adopted by Cenpec is that everyday life is the basis for the formation of individuals. Everyday life is seen as a space where objectives include human actions and the results of knowledge that is produced. That is, increasing time spent at school is not only meant to improve school performance. In addition to the number of hours spent with educational activities, qualitative improvement is also important throughout the school day, opportunities in which "content can be reinterpreted by and assume an exploratory and experiential nature for all those involved..." (Gonçalves, 2006, p. 132).

Given what is provided in the legislation, a progressive increase in the time children and adolescents remain at school, or in educational areas linked to public policies, or private or non-governmental organizations, has been observed confirming the historical importance of educational spaces for subjective constitution (Tomás, 2001). We take the term subjective constitution, as Maheirie (2002) and Zanella (2006) have taken it, that is, understood as an alternative to the terms personality or identity, which refer to a closed, finished structure, conveying an idea of sameness and stiffness. We understand psychological processes as open, unfinished processes, produced in relationships among the subjects, based on the historical-cultural psychology that contributes to conceiving the subject as multiple relationships.

Extended school days are characterized as a socioeducational complement to the activities provided at school, with systematic and planned actions, involving educational, cultural and sports practices for children and young individuals aged from 6 to 14 years old.

Workshops with varied artistic languages and projects are frequently included. Various educational projects linked to NGOs present artistic activity as the centerpiece of its proposals. Examples include the following projects: Axé Bahia, in Salvador; Travessia (Crossing) in São Paulo; Quayside in Recife, among others (Barbosa, 2007). Other educational spaces with varied characteristics and conditions include artistic activities in their routine, such as socioeducational measures linked to Social Work Departments; after-school programs linked to the Department of Education and regular schools that develop programs to assist students full time and provide diverse artistic workshops.
Additionally, authors mention the inexhaustible potential of art in the educational sphere in regard to projects of social inclusion (Bay, 2007; Barbosa, 2007; Fernandes et al., 2006). In this direction, authors suggest that the inclusion of artistic activities in after-school projects would enable students to access aesthetical knowledge.

In general, however, there is an expectation among educational organizations in which art is taught that work with art has repercussions on education, learning conditions, on the training of young individuals, and on reducing academic failure (Fernandes et al., 2006). Additionally, art is included in these spaces following the perspective of risk prevention or fight against violence, characterizing a utilitarian appropriation of artistic activity to compensate for neglecting an entire social logic.

Despite this perspective of limiting risk or preventing violence, it is important to consider that artistic activities, whether they are directed to a young public with difficulty accessing income, education, or who are involved with child labor, abuse, neglect, or whether they are directed to young individuals in favorable social and economic conditions, these activities can broaden one's aesthetic experience and proximity to artistic manifestations, both those historically acknowledged and non-hegemonic ones (Bay, 2007; Urnau, 2008).

Therefore, depending on the quality of these activities, they can lead to transformations in the conditions of existence of these individuals because "art is the organization of our future behavior. It is a requirement that may never be fulfilled but that forces us to strive beyond our life toward all that lies beyond it" (Vygotsky, 2001, p. 320).

Considering this possibility is a good opportunity to discuss how scientific research has followed this social movement meant for the youth, this study is characterized as a state of art or state of knowledge and its objective was to identify and analyze theses and dissertations defended in Brazilian graduate programs addressing the study of artistic activities in programs intended to extend the school day. We consider it relevant to map these studies and investigate how they discuss these artistic activities in these spaces and how young individuals and educational institutions relate in this modern context, considering the potential contributions to proposals to expand the school day.

\section{Method}

As previously mentioned, this study is characterized as state of art or state of knowledge because of its bibliographic and descriptive nature (Ferreira, 2002; Zanella \& Titon, 2005). The identification and discussion of academic production in different fields of knowledge concerning the presence of school activities in after-school programs considered the ways and conditions master's theses and doctoral dissertations are developed. Therefore, we highlight aspects and dimensions that have priority in certain times and different places (Ferreira, 2002). 


\section{Procedure}

Data collection. It was restricted to dissertations and theses defended in Brazilian graduate programs available on the website for the Coordination for the Improvement of Higher Education (CAPES) between 2000 and 2012 (CAPES, 2011). Initially, theses and dissertations were identified using the descriptors "art" and "education, primary and secondary": Two hundred and ninety-three abstracts were found in the online CAPES database theses and dissertations. Considering the many possibilities of studies with art and education, a new search was performed using more specific descriptors: "art" or "artistic activity", "Informal education", "full-time education" or "complementary education" in different combinations.

At this point, when the quantification and identification of bibliographic data was necessary, we found 16 studies addressing art and informal education, 57 with art and complementary education, 51 with art and full-time education, 19 with artistic activity and full-time education, 16 with artistic activity and complementary education and two studies with the descriptors artistic activities and informal education. In total, 161 studies were found; only one copy of those appearing more than once, as descriptors were changed, was considered. These combinations of descriptors were used to locate studies that addressed the topic and were essential, in order to exclude studies that did not include the specific terms in their titles.

As noted in another study (Assis \& Zanella, 2012), these programs are named differently based on the public policy to which they are linked and to their target public, such as: Extended School-Day, Complementary Education, Full-Time School or After-School Program. For this reason, changing the combination of descriptors aided the identification of studies, the main focus of which was not an extended school day in educational contexts or with artistic activities. We found studies linked to nursing, religiosity, the education of health professionals, architecture, art therapy, homeless adults, and educational law, among others. A total of 112 studies were excluded, while 49 studies were analyzed.

Information was organized in tables to facilitate the process, which resulted in a database for the study. Analysis was first focused on the titles because these provided information on the main topic or the elements characterizing the study.

Data analysis. Following this, we had an inventory of the studies found. This procedure consisted of identifying studies based on criteria proposed by the methods of Santos (1995) and Zanella and Titon (2005), such as: (a) identification of the geographic location; (b) identification of graduate degree; (c) identification of field of knowledge; (d) study's main theme; (e) theoretical framework; (f) type of study; (g) methodological procedures; (h) artistic activities involved in the educational organizations; and (i) study's main results. In contrast with what is proposed by Santos (1995), in which subcategories were created before analyzing the documents, in this study we opted to establish subcategories after reading each abstract That is, the subcategories were developed in the investigation process.

Therefore, 49 studies were analyzed through reading the abstracts, material considered essential in the database search, which allow readers to ascertain a study's objective, method, results and conclusions. Compared to the titles and key words, the abstracts enable a broader investigation, with greater dissemination of studies. The abstracts enabled verifying the literature state of the art even though many were poorly written and despite the "heterogeneity of textual and typographic marks" (Ferreira, 2002, p. 265).

After reading the abstracts, the subcategories were established and full texts were consulted in some cases. Identification of the geographic locations of the studies were classified into the subcategories: South, Northeast, Midwest, Southeast, and North. Identification concerning graduate degrees included Master's of Science, Master's of Advanced Studies, and PhD. In regard to field of knowledge, other seven subcategories were created: Education, Social Sciences, Physical Education, Psychology, Social Work, Arts and other fields.

Seven subcategories emerged from the main theme category: (a) pedagogical proposals with the inclusion of arts (studies that focused on the analysis of pedagogical proposals that value the practice of art within schools); (b) politicalcultural movements and informal education: characterized by studies not linked to formal education but related to organizations from civil society, such as associations, entities ensuring social rights, non-governmental networks focusing on promoting social activities, among others (Ministério da Integração Nacional, 2013), and which highlighted political issues; (c) aesthetic experience in teaching and learning contexts (analyses focusing on the study of artistic experiences without linking them to a specific proposal or organization); (d) actions complementing formal education and the rights of children and adolescents (studies highlighting the rights and enforcement of the Child Statute coupled with art activities); (e) community psychology; and also (f) Other less frequent themes that were grouped into a single category.

The theoretical framework category was subdivided into: Liberating Pedagogy/criticism (all the studies based on critical theories of education, some of them having Paulo Freire as the main author researched, others from the sociological perspective of Pierre Bordieu); Multiframework approaches (those investigations that used diverse theoretical references in the same study); Unidentified (when the theoretical framework was not clear); and Others (studies whose theoretical references appear less frequently were grouped together).

The categories established by Santos (1995) and Zanella and Titon (2005) in their studies, as well as their definitions, were also used in this study in the category regarding type of study. Theoretical studies included those analyzing a given object of study in light of a literature review or existing 
theories, in addition to those presenting critical analyses of theoretical positions. Experimental studies included scientific investigations manipulating one or more variables based on determining one object of study, the selection of variables and definition of forms of control and the observation of effects that the variables produce on the object.

Documental research includes all studies in which the methodological focus was documents, such as: educational proposals and curricula, photo albums, newspaper clippings. For instance, post facto research grouped studies addressing situations that occur naturally. Survey studies include those addressing a given object through surveying people, such as, outlining the profile of a population using questionnaires. Case studies refer to broad and exhaustive research on a given object. Finally, the Others category grouped studies that did not fit into any of the previous categories (Santos, 1995).

Subcategories were created in regard to methodological procedures: (a) documental study; (b) observation/filming of artistic workshops; (c) diverse procedures; (d) semistructured interviews; (e) unidentified; and (f) others.

In regard to the artistic activities involved in the educational spaces addressed in the theses and dissertations, we sought to organize them according to the four artistic modalities proposed in the National Curricular Parameters (1997): (a) Visual Arts, which comprise graphic arts, video, cinema, photograph, and new technologies such as computer art; (b) Music; (c) Theater; and (d) Dance (Ministry of Education, 1997). We added three categories to these due to the study's characteristics: (e) diverse languages: for studies with different artistic languages; (f) unidentified: for those in which the modality of artistic activity addressed was not clearly stated; and $(\mathrm{g})$ others, for recreational activities and Chinese body art.

Finally, the following subcategories were established for the category Studies' main results: (a) importance of creative education within institutional contexts gathered studies that highlighted the importance of artistic activity in extra-curricular education programs; (b) relationship between arts and psychological functioning refers to studies that produced knowledge relating the contribution of arts to psychological issues and human development; (c) arts and collective action gathered studies acknowledging the possibilities of art enabling political education and collective action among participants; (d) others include less frequent results, such as findings related to the teaching of specific artistic languages and contributions to environmental education; and (e) unidentified.

\section{Results and Discussion}

The results presented include the 49 abstracts of the studies analyzed in the diverse aspects previously mentioned. We start by presenting those concerning the geographic location of the studies. The Southeast and South stood out with $44.90 \%$ and $26.53 \%$ of dissertations and theses, respectively, while the Northeast presented $20.41 \%$; the
North 2.04\%; and the Midwest 6.12\%. These results reflect the fact that, historically, the universities were initially established in the Southeast region, as Francisco (2002) and Zanella and Titon (2005) note.

On the other hand, it is noteworthy that similar figures were observed in the South and Northeast. Two reasons can explain such a result: even though the graduate system in the South has been established much longer, the system has grown much more in the last three years in the Northeast, according to the Report of Final Results concerning the Triennial Assessment 2010, CAPES (2010). Another possible explanation refers to the characteristics of these two regions and the extent to which cultural activities are valued. To be certain of such results, however, further investigation is required that is beyond this study's scope.

In regard to graduate degrees, $77.55 \%$ of the studies were conducted at the Master's level, $20.41 \%$ at the doctoral level, and $2.04 \%$ in Master's of Advanced Studies. The Master's of Advanced Studies was regulated by Decree No. 7, June 23, 2009 (Ministério da Educação, 2009b) and its objective is education with an emphasis on technical applicability and operational flexibility. Therefore, taking into consideration that this is recent regulation and the search in the database went up to 2012, it was expected that few studies in this modality of graduate programs would be found. The difference in the number of theses and dissertations is explained by the characteristics of the Brazilian graduate system itself, with a recent emphasis on doctoral programs and the creation of doctoral programs, more specifically the considerable difference in the number of those who have attained a Master's and those who have attained a doctorate, the information of which can be found in the beginning of the paragraph.

In regard to the field of knowledge, $53 \%$ of the abstracts referred to the field of Education; followed by the Social Sciences and Physical Education, which accounted for $8.18 \%$ of the abstracts each; Psychology, Social Work, and Arts, which accounted for $6.15 \%$ each; other fields, less frequently found, such as Environmental Education, Theology, Regional Development, and Linguistics together accounted for $12.19 \%$ of the abstracts.

The field of Education accounts for the highest number of studies. This finding is explained by the fact that artistic activities take place after school and complement activities provided by the school, and as mentioned in other studies, are created to overcome obstacles found by education professionals with purposes linked to school performance (Assis \& Zanella, 2012). Even though the discourse of interdisciplinary studies in the production of knowledge is a recurrent topic and Education may be seen as a comprehensive discipline transversal to the others indicated in this category, there still is a certain preference in scientific research for unidisciplinary studies.

In the category study's main theme, the studies addressing pedagogical proposals with the inclusion of arts accounted for $24.49 \%$ of the studies; political, cultural 
movements and informal education accounted for $18.37 \%$. We found that aesthetic experiences in learning teaching contexts accounted for $12.24 \%$; actions complementary to school and the rights of children and adolescents, for 20.41\%; Community Psychology, for 16\%; and other less frequent topics, such as Environmental Education and Arts, accounted for $8.49 \%$.

Even though most studies are from the field of education, it is interesting to note there is no correspondence between indicators of these studies (53\%) and the main category of study. In this case, $24.49 \%$ of the 49 Theses and Dissertations focused on pedagogical proposals with the inclusion of arts. This is close to studies investigating political, cultural or artistic movements and informal education, which may indicate that discussions in the field of education have also included ethical, aesthetic and political issues faced by society.

In regard to the theoretical framework, $32.65 \%$ of the studies did not clearly state the theoretical basis of the study. The abstracts show that, even though it is not explicitly stated, some studies simply confirmed the assumptions of the educational organizations they addressed. Sometimes, they indicated what categories were investigated but did not present the theoretical framework supporting the concepts presented. Other studies, also with no identifiable theoretical basis, presented investigations linked to human rights or the social sciences in which the concepts adopted were related to references and techniques concerning current public policies and laws. Therefore, abstracts need to be formalized so as to make it explicit, whenever the case, the theoretical framework adopted.

Still concerning the theoretical framework, the second most frequent studies were those with-multi theoretical approaches, with $16.33 \%$; that is, diverse approaches were used in the same study. For example, Silva (2006) assumes the theoretical basis of her method to be "multi-referential" and qualitative for the description and interpretation of knowledge, but only indicates the bibliographic research, the qualitative field research and the study's analysis and reflection on the topic.

According to Ardoino (1995), a multi-referential perspective is considered a new epistemological perspective in the construction of knowledge of social phenomena, especially educational phenomena. This does not mean that multi-referential studies can merely gather antagonistic theoretical perspectives, because, as noted by Ardoino, the understanding of reality takes place when one appeals to systems of reference, from different perspectives (psychological, psychosocial, sociological). In Silva, as well as in other theses and dissertations, the multi-referential nature occurred, without, however, making explicit the epistemological implication described by Ardoino.

Another subcategory that also accounted for $16.33 \%$ of the studies were those using the assumptions of the liberating pedagogy or criticism (such as the contributions of Paulo Freire and Bordieu). Other studies with less frequent references totaled $34.69 \%$, with $4 \%$ each, namely: the Complexity Theory of Edgar Morin, Michel de Certeau, Michael Foucault, Spiritual/religious assumptions, Gilles Deleuze, the Ecological Theory of Human Development, the Psychogenic Theory of Henri Wallon, and authors in the field of the arts.

We stress the fact that various studies elected theoretical perspectives questioning homogenizing and institutionalized practices or made social critiques on the function of these educational spaces.

We also note studies based on religious theoretical bases. These studies emerge as, historically, actions complementary to school were implemented by NGOs and by organizations in civil society, which are often characterized by entities linked to religious, spiritual or philanthropic purposes. Therefore, it is not surprising that some studies carry the values of the institutions they study.

In regard to the type of study, $42.86 \%$ were case studies; $20.41 \%$ were documental research; $8.16 \%$ were theoretical studies like literature reviews, the same percentage obtained by ex post facto studies (study of situations that occurred naturally) and others not identified through the reading of abstracts; $12.24 \%$ of the abstracts refer to surveys (questioning individuals). None of the studies were identified as experimental research; that is, no studies are represented here that manipulate variables based on determining an object of study or the definition of forms of control and observation of the effects that variables produce on the object. In contrast, a large number of case studies were observed; the investigations focused on practical problems and were based on populations of reference.

Additionally, we assert that studies that value the complexity of a particular phenomenon are characterized by concrete, contextualized investigations. Thus, case studies are appropriate to provide information for decision-making concerning educational policies.

In regard to methodological procedures employed in the studies: $22.45 \%$ referred to the study of documents like curricula, photographs, artwork, drawing and music albums; $18.37 \%$ observed artistic workshops developed in a social setting and projects; and $14.29 \%$ used various procedures (analysis of documents, questionnaires, interviews, focal groups, portfolio analysis). Some studies (10.20\%) used semi-structured interviews. The same percentage was observed in the case of studies that did not clearly state the procedure adopted. Finally, studies with less frequent procedures were grouped in the subcategory others and totaled $24.48 \%$ (participant observation, survey-action, focal groups, longitudinal studies, and studies of theories, proposing theoretical bases for specific fields in the arts). These findings show the diversity of procedures used in scientific research in this context.

The subcategory with the largest percentage in terms of methodological procedures was the study of documents $(22.45 \%)$, which is considered a non-invasive way of 
obtaining data because it does not involve the direct collection of information from people participating in the study (Spink, 2007). The other subcategories, considered to be invasive ways of collecting data, totaled $55.1 \%$.

Considering the characteristic of these procedures, we can state that there are new relationships among those involved in research (Spink, 2007). The researcher and the subject or context under study were involved in methodological procedures that break with the precepts of the epistemology of distance. Participating in an artistic workshop or visiting an educational organization demand a different perspective that implies giving up the illusion of the possibility of a neutral record.

Even though the studies did not clearly state their methodological procedures, that is, the research process per se, there were some indications that allow us to draw some conclusions regarding the posture required from the researcher when producing knowledge this way. The emphasis in the investigation of Zanatta (2004) was on participative observation. Another study addressed hip-hop and popular education in the context of the state of Maranhão, Brazil. The researcher was inserted in the group under study (Santos, 2007). We should clarify that hip-hop is a political/aesthetic movement that was initiated in the 1960s in the USA involving Rap (music), Breakdancing (dance) and Graffiti (Visual Arts). Hip-hop is currently present in different countries such as Brazil, especially in urban areas (Hinkel \& Maheirie, 2007).

We also highlight the study by Silva (2006) in which the description and understanding of knowledge concerning fishing was sought. In this study, the experience and familiarity shared by the researcher with the study's subjects was extremely important to the study's description and the reflection contained in the study. These are three studies, among others, that indicate and appreciate the relationship of the researcher with the subjects under study. The researcher is not an evaluator of the process, rather the researcher is a participant member who shares experiences and produces knowledge based on the encounter, on the event.

In regard to the artistic activities involved in educational spaces, $24.49 \%$ were not clear as to what type of artistic language was involved in the study; that is, they conducted the investigation without highlighting or making explicit whether the artistic activity was music, plastic arts, or other. A total of $20.41 \%$ of the studies focused on visual arts; $16.33 \%$ included diverse artistic languages in the same study; music, theater and dance represented $8.16 \%$ of the studies, each; and other less frequent languages totaled $14.29 \%$ (i.e., recreational activities and Chinese body art).

We ask one important question: to what was the researcher paying attention in these investigations such that there is no mention of the type of artistic activity in a study in which the descriptor is art or artistic activity? It is essential to understand the place that Art occupies in educational projects in a social context and to identify and recognize what type of Art one is discussing.
Some studies mention the fact that Art has a utilitarian role, as a means to achieve educational objectives other than those linked to the art itself, such as working knowledge and skills not promoted by regular teaching (Bay, 2007; Fernandes et al., 2006).

The last category verified referred to the main results obtained or produced by the studies. The percentages were: The importance of creative education in institutional contexts (26.53\%); Relationship between arts and the psychological functioning (22.45\%); Arts and collective action (20.41\%); unidentified $(8.16 \%)$; and other studies, the results of which were less frequent $(22.45 \%)$. A certain balance is observed in terms of the percentages among the categories. At the same time in which the results of studies were focused on the art's aesthetic and creative issues, they also reported the contribution of arts to psychological, singular development, and with similar percentages, the results also acknowledge art as collective, political action.

The study of Soares (2004), for instance, when analyzing artistic and cultural activities, concluded that new educational practices adopted in a space outside of school enable individuals to enjoy creative experiences that contribute to their integral education as individuals who actively participate in the community.

Note that at the beginning of this state of art study we found 293 abstracts and only 49 referred to diverse educational contexts. It is worth noting that there are other forms of education, other informal or not-institutionalized community spaces, which often provide young individuals with meaningful educational possibilities directed to specific social demands of a given context or generally public context.

\section{Final Considerations}

This study's aim was to map and investigate how theses and dissertations discuss the inclusion of artistic activities in after-school programs, as well as the relationship between young individuals and educational institutions in the current context.

This study enabled reaching some conclusions in regard to new ways of doing research in educational contexts and to the opportunities of aesthetic education currently available to young individuals.

Diverse ways of doing research, theoretical assumptions, study designs and a diversity of methodological procedures were highlighted in the analysis of educational contexts provided in the theses and dissertations under study. We find that the scope of the contexts under study, as well as the complexity of the relationships established among people, and the configurations of the educational projects, required researchers to adopt different methodological postures. Interviewing young individuals participating in educational workshops, observing and filming artistic activities and even studying photo albums or written documents constitutes a dialogical event in which the subject under study is a condition for the production of knowledge and for the researcher's very condition as researcher. 
The abstracts indicated that the studies used combinations of methods of investigation, a bricolage of possibilities and concepts, methods, and research procedures. We also observe that the case studies $(42.86 \%)$ were the investigations that more clearly presented a connection with some theoretical assumption and made clear the authors and concepts linked to their fields of study. They elected projects treating education with art as the focus of investigation and explicitly defined in the studies' abstracts the epistemological basis of the studies.

It is clear that even though education was the field of knowledge with the highest percentage of studies identified, the theme of this state of art is interdisciplinary and is congregated in various fields of knowledge in the understanding the study's problems. The theme of study with the highest percentage was pedagogical proposals with the inclusion of arts $(24.49 \%)$ considering that education was the field of knowledge most frequently involved.

We consider it to be significant that many studies (18.37\%) focused on cultural political movements involved in informal contexts of education. That is, education as a social institution essential for the constitution of subjects, and society itself is hegemonic but expresses social movements, resistance, opposition to mainstream culture, to the way of understanding social organization.

Another aspect worth highlighting in the conclusion of this state of art refers to the type of artistic activity involved in the investigation, considering that $24.49 \%$ of the studies did not report the type of artistic activity under study. It is necessary to discuss the conception of Art and the place it occupies in educational projects, considering the increasing inclusion of artistic activities in the most diverse social and educational projects.

There are other forms of education, other informal or non-institutionalized community spaces that provide young individuals with meaningful educational possibilities connected with specific social demands of a given context and which can be characterized as an interesting strategy of coexistence and social construction. We highlight educational projects that included Art and happened in the streets, in neighborhood associations, in NGOs, linked to a given local social movement, and which contribute to discussion of ways of doing school. The investigations indicated that their results reflect changes that took place in the lives of young individuals when they participated in educational projects including Art and, at the same time, verified possibilities of social mobilization through these encounters.

Therefore, we find that beyond extending the time young individuals spend within the institution, it is essential to extend educational possibilities to other spaces. In this sense, we also understand that the city is an educator to the extent modern young individuals demand the ability to circulate in diverse learning spaces.

Longer periods of study, however, should be accompanied by access to the various spaces where the city and its knowledge is appropriated so that the educational project does not represent a limiting circumstance. We understand that the time individuals remain in the institution should be qualitatively transformed to a period that gives priority to multiple experiences and languages and, in this direction, Art can contribute to the subject's aesthetic education.

Finally, this state of art can guide new research projects in graduate programs and there is also the possibility that other studies addressing this research problem could focus on papers published in scientific journals.

\section{References}

Ardoino, J. (1995). Le directeur et l'intelligence de l'organization: Repéres et notes de lecture. Ivry, France: Andesi.

Assis, N., \& Zanella, A. V. (2012). Jovens e programas de contraturno escolar: (Des)encontros possíveis. Pesquisa e Práticas Psicossociais, 7(1), 76-82. Retrieved from http://www.ufsj.edu.br/portal2-repositorio/File/ revistalapip/Volume7_n1/Assis_e_Zanella.pdf

Bay, D. M. D. (2007). Resgatando arte, incluindo a arte. In A. V. Zanella, F. C. B. Costa, K. Maheirie, \& S. Z. Ros (Orgs.), Educação estética e constituição do sujeito: Reflexões em curso (pp. 29-36). Florianópolis, SC: NUP/CED/UFSC.

Barbosa, A. M. (2007). Arte/educação e diferentes conceitos de criatividade. In A. V. Zanella, F. C. B. Costa, K. Maheirie, \& S. Z. Ros (Orgs.), Educação estética e constituição do sujeito: Reflexões em curso (pp. 23-28). Florianópolis, SC: NUP/CED/UFSC.

Centro de Estudos e Pesquisas em Educação, Cultura e Ação Comunitária. (2013). Quem somos. São Paulo, SP: CENPEC. Retrieved from http://www.cenpec.org. br/quemsomos

Coordenação de Aperfeiçoamento de Pessoal de Nível Superior. (2010). Relatório de divulgação dos resultados finais da avaliação trienal 2010. Retrieved from http://trienal.capes.gov.br/wp-content/ uploads/2011/08/relatorio_geral_dos_resultados_finais_da-avaliacao_2010.pdf

Coordenação de Aperfeiçoamento de Pessoal de Nível Superior. (2011). Banco de teses. Retrieved from http:// www.capes.gov.br/servicos/banco-de-teses

Fernandes, A. M. D., Moura, A. M. A., Fernandes, D. J., Rocha, G. F., Luna, G. C. V., \& Barbosa, T. L. O. (2006). Cidadania, trabalho e criação: Exercitando um olhar sobre projetos sociais. Revista do Departamento de Psicologia, UFF, 18(2), 127-143. doi:10.1590/S0104-80232006000200010

Ferreira, N. S. A. (2002). As pesquisas denominadas "estado da arte”. Educação \& Sociedade, 23(79), 257-272. doi:10.1590/S0101-73302002000300013

Francisco, P. R. (2002). Tendências nas dissertações e teses em psicologia sobre as dificuldades de aprendizagem escolar na segunda metade da década de 90 (Unpublished marter's thesis). Universidade Federal de Santa Catarina, Florianópolis, SC. 
Gonçalves, A. S. (2006). Reflexões sobre educação integral e escola de tempo integral. Cadernos Cenpec: Educação Integral, 1(2), 129-135.

Hinkel, J., \& Maheirie, K. (2007). Rap-rimas afetivas da periferia: Reflexões na perspectiva sóciohistórica. Psicologia \& Sociedade, 19(2), 90-99. doi:10.1590/S0102-71822007000500024

Lei $n^{\circ}$. 9.394, de 20 de dezembro. (1996, 23 de dezembro). Estabelece as diretrizes e bases da educação nacional. Diário Oficial da União. Retrieved from http://www. planalto.gov.br/ccivil_03/leis/L9394.htm

Maheirie, K. (2002). Constituição do sujeito, subjetividade e identidade. Interações, 7(13), 31-44.

Ministério da Educação. (1997). Parâmetros curriculares nacionais: Arte. Brasília, DF: MEC/SEF.

Ministério da Educação. (2009a). Programa Mais Educação: Passo a passo. Brasília, DF: MEC. Retrieved from http://portal.mec.gov.br/dmdocuments/passoapasso_ maiseducacao.pdf

Ministério da Educação. (2009b, de 23 de junho). Portaria no . 7 , de 22 de junho. Dispõe sobre o mestrado profissional no âmbito da Fundação Coordenação de Aperfeiçoamento de Pessoal de Nível Superior - CAPES. Diário Oficial da União, seção 1. Retrieved from http://portal.mec.gov.br/ dmdocuments/port_mestrado_profissional1.pdf

Ministério da Integração Nacional. (2013). I Conferência Nacional de Desenvolvimento Regional: Segmentos da Conferência Estadual. Retrieved from http://www. integracao.gov.br/web/cndr/etapa-estadual

Santos, A. T. (1995). Estudo da criatividade no Brasil: Análise das teses/dissertações em psicologia e educação (1970/1993) (Unpublished master's thesis). Universidade Estadual de Campinas, Campinas, SP.

Santos, R. E. (2007). Hip hop e educação popular em São Luís do Maranhão: Uma análise da organização "Quilombo Urbano” (Unpublished master's thesis). Universidade Federal do Maranhão, São Luís, MA.

Silva, H. N. S. (2006). Zingando nos saberes de caetanos de cima (Unpublished master's thesis). Universidade Federal do Ceará, Fortaleza, CE.

Spink, M. J. P. (2007). Pesquisando no cotidiano: Recuperando memórias de pesquisa em psicologia social. Psicologia \& Sociedade, 19(1), 7-14. doi:10.1590/S0102-71822007000100002

Soares, S. J. (2004). Barracões culturais da cidadania: Espaço de reflexão e práticas (Unpublished master's thesis). Universidade Metodista de São Paulo, São Paulo, SP.

Tomás, C. A. (2001). A transformação da infância e da educação: Algumas reflexões sócio-históricas. Paidéia (Ribeirão Preto), 11(21), 69-72. doi:10.1590/S0103-863X2001000200008

Urnau, L. C. (2008). Juventude e arte: Os sentidos da mediação artística para jovens participantes de projetos sociais (Unpublished master's thesis). Universidade Federal de Santa Catarina, Florianópolis, SC.
Vigotski, L. S. (2001). Psicologia da arte (P. Bezerra, Trad.). São Paulo, SP: Martins Fontes.

Zanatta, D. P. (2004). O Ballet: Uma arte erudita num contexto escolar popular (Unpublished master's thesis). Pontifícia Universidade Católica do Rio Grande do Sul, Porto Alegre, RS.

Zanella, A. V., \& Titon, A. P. (2005). Análise da produção científica sobre criatividade em programas brasileiros de pós-graduação em psicologia (19942001). Psicologia em Estudo, 10(2), 305-316. doi:10.1590/S1413-73722005000200018

Zanella, A. V. (2006) Pode até ser flor se flor parece a quem o diga: reflexões sobre educação estética e o processo de constituição do sujeito. In S. Z. Da Ros, K. Maheirie, \& A. V. Zanella (Eds.), Relações estéticas, atividade criadora e imaginação: sujeitos e (em) experiência. Florianópolis, $\mathrm{SC}: \mathrm{NUP} / \mathrm{CED} / \mathrm{UFSC}$.

Neiva de Assis is a Professor of the Instituto Federal Catarinense.

Andrea Vieira Zanella is an Associate Professor of the Centro de Filosofia e Ciências Humanas at the Universidade Federal de Santa Catarina.

Luciano Rosa is a Professor of the Instituto Federal Catarinense.

Received: Mar. 19, 2013

1st Revision: Dec. 18, 2013

Approved: Mar. 17, 2014

How to cite this article:

Assis, N., Zanella, A. V., \& Rosa, L. (2014). The extended school day and artistic activities: Analysis of scientific production between 2000 and 2012 . Paidéia (Ribeirão Preto), 24(58), 253-260. doi: 10.1590/1982-43272458201413 